\title{
Effect of enzyme concentrations on total reducing sugar from leftover croissants and doughnuts via enzymatic hydrolysis
}

\author{
${ }^{1}$ Mohd Thani, N., ${ }^{1, *}$ Mustapa Kamal, S.M., ${ }^{1}$ Taip, F.S., ${ }^{1}$ Sulaiman, A. and ${ }^{2}$ Omar, R. \\ ${ }^{1}$ Department of Process and Food Engineering, Faculty of Engineering, Universiti Putra Malaysia, 43400 \\ Serdang, Selangor, Malaysia. \\ ${ }^{2}$ Department of Chemical and Environmental Engineering, Faculty of Engineering, Univeristi Putra \\ Malaysia, 43400 Serdang, Selangor, Malaysia.
}

\author{
Article history: \\ Received: 19 September 2018 \\ Received in revised form: 19 \\ November 2018 \\ Accepted: 21 November 2018 \\ Available Online: 28 \\ November 2018 \\ Keywords: \\ Leftover, \\ Croissants, \\ Doughnuts, \\ Enzymatic hydrolysis, \\ Sugar recovery
}

DOI:

https://doi.org/10.26656/fr.2017.3(4).140

\section{Introduction}

Bakery waste is one of the major contributors to global food waste, which is about 1.2 million tones were disposed of every year (Melikoglu and Webb, 2013). According to Adhikari et al. (2006) due to its biological degradation, bakery waste may cause the released of hazardous gas, such as methane and carbon dioxide that indirectly leading to Green House Gas (GHG) emission.

Most of the bakery wastes are rich in carbohydrates and sugars in its formulations, along with very short shelf life, making it a potential raw material for producing valuable products. Various type of end products has been obtained by using bakery wastes as renewable raw materials, such as sugars, biofuel, enzymes, acids and aromatic compounds. However, only a few studies have been carried out on utilizing bakery wastes for sugar production. The common method in recovering sugar from bakery wastes is via enzymatic hydrolysis. This method considered to use less energy and requires mild environment condition along with low toxicity, utility cost as well as reduce corrosion when compared to acid hydrolysis (Sun and Cheng, 2002).

Holck et al. (2011), Menezes et al. (2009), and Ramirez-Coutino et al. (2006) proved that enzymatic hydrolysis is efficient and produced a high yield of sugars compared to acid hydrolysis or autohydrolysis.
Recent studies on optimization of enzymatic hydrolysis of bakery wastes in producing sugars were carried out by Demirci et al. (2017) and Hudečková et al. (2017).

Among the wide ranges of sugar, total reducing sugar is a type of sugar that has a free aldehyde or a ketone group, which allows the sugar to act as a reducing agent (Kunz et al., 2011). Generally, all monosaccharides are reducing sugar, while only some are disaccharides. During a chemical reaction, the aldehyde and ketone group within reducing sugar molecule can donate an electron to other molecule causing the chemical changes. These changes might affect the colour and taste of the food, through a process, known as Maillard reaction (Foist, 2018). Hence, by determining the yield of reducing sugar recovered via enzymatic hydrolysis will provide a better understanding of the reaction mechanism between various bakery wastes.

Although there were some studies utilized bakery waste for recovering sugar, most of its were utilizing white bread as raw materials out of many of bakery wastes products. Each bakery wastes product has different formulations. Therefore, this study is focusing on recovering total reducing sugars from leftover croissants and doughnuts. The aims of this research are to study the effect of enzyme concentration on the total 
reducing sugar recovery during enzymatic hydrolysis of leftover croissants and doughnuts.

\section{Materials and methods}

\subsection{Raw materials}

Croissants and doughnuts were obtained from a local bakery in Selangor, Malaysia and left in room temperature that had passed its shelf life (three days). The raw materials showed no signs of mold growth. Initially, doughnuts leftover were characterized via proximate analysis using the AOAC method (AOAC, 2000) to determine its carbohydrate compositions (AOAC, 2000). The carbohydrate content of croissants was found to be $50.07 \pm 2.49 \%$ while for doughnuts, $44.94 \pm 1.69 \%$.

Afterwards the raw materials were ground to powder form using laboratory knife mill, and then vacuum packed before being stored at $-20^{\circ} \mathrm{C}$ until use. All analysis were done in triplicate $(\mathrm{n}=3)$.

\subsection{Enzyme}

Sigma 10113 Amyloglucosidase produced from Aspergillus Niger was purchased from Sigma Scientific. The enzyme unit is $120 \mathrm{U} / \mathrm{mg}$.

\subsection{Enzymatic hydrolysis}

For the enzymatic hydrolysis, $1.5 \mathrm{~g}$ of substrate was mixed with $30 \mathrm{ml}$ of distilled water in the Erlenmeyer Flask at various levels of enzyme concentrations $(0.1$, $0.3,0.5,0.7,0.9,1.0 \mathrm{w} / \mathrm{w} \%)$, were added and the $\mathrm{pH}$ of the slurry was adjusted to $\mathrm{pH} 5.5$ using $1 \mathrm{~mol} \mathrm{~L}^{-1} \mathrm{H}_{2} \mathrm{SO}_{4}$ or $\mathrm{NaOH}$ solutions. The flasks were placed in the incubator shaker $(200 \mathrm{rpm})$ for 24 hours at temperature of $55^{\circ} \mathrm{C}$. The enzyme activity was ended by heating of the suspension at $80^{\circ} \mathrm{C}$ for 5 mins.

\subsection{Total reducing sugar analysis}

The reducing sugar content was determined using dinitrosalicylic acid method (Chaplin and Kennedy, 1986). A diluted hydrolysate sample $(0.2 \mathrm{~mL})$ was combined with $2 \mathrm{~mL}$ DNS acid solution. Next, the sample was placed in boiling water for 10 mins and then cooled to room temperature. The absorbance at $570 \mathrm{~nm}$ was recorded. The standard curve was prepared following the same procedure by replacing the sample with glucose (Klinchongkon et al. 2017).

\subsection{Statistical analysis}

Design Expert software (Stat Ease Corp, USA) was used to study the effect of independent variables, enzyme concentration (w/w substrate) on croissants and doughnuts leftover. In this study, total carbohydrates were selected as the response.

\section{Results and discussion}

\subsection{Total reducing sugar analysis}

Figure 1 displays the total reducing sugar from the enzymatic hydrolysis of croissants and doughnuts leftover. Initially, the trends for enzyme concentrations $0.1 \%$ until $0.5 \%$, were quite similar for both pastry products. Increased of the total reducing sugar was parallel with the addition of enzyme amyloglucosidase. During this phase, known as the starch hydrolysis (saccharification), dextrin was produced by breaking down the $\alpha$-1,4-glycosidic bond in the middle of amylose and amylopectin chain and saccharified by amyloglucosidase to obtain monomeric sugars (glucose). The increasing amount of total reducing sugar was expected as increasing the enzyme concentration increases the availability of enzymes per unit substrate, more mass transfer and enzyme transport to the surface of the starch granules. All these factors can directly lead to high conversion efficiency. The same trend was discovered by Chen et al. (2008), in the enzymatic hydrolysis of maize straw polysaccharide to produce reducing sugar, it was found that the amount of enzyme per substrate increased resulted in higher hydrolysis yield.

However, in this study, there was a slight difference in the amount of total reducing sugar trend as the enzyme concentration increased. Leftover croissants showed a somewhat sharp increase in the total reducing sugar at the enzyme concentration $0.5 \%$ to $0.7 \%$. The highest total reducing sugar for leftover croissants was recorded at $\quad 0.7 \%$ enzyme concentration $(5.30 \pm 0.03 \mathrm{~g} / \mathrm{L})$. Nonetheless, a further increase in enzyme concentration had caused a decrease in the total reducing sugar yield. This may be due to less substrate available for enzyme attack, thus decreasing the conversion efficiency.

On the other hand, the total reducing sugar trend for doughnuts leftover displayed a continuous insignificant increase throughout the enzyme concentration of $0.5 \%$ until the maximum enzyme concentration was added. Sufficient enzyme dosage and low substrate concentration is one possible explanation for why little difference in hydrolysis yield was observed at different enzyme concentration. The highest total reducing sugar obtained from enzymatic hydrolysis of doughnuts was $4.71 \pm 0.54 \mathrm{~g} / \mathrm{L}$ from enzyme concentration of $1 \%$.

The divergence of total reducing sugar results for both leftover croissants and doughnuts possibly can be related to the variation of these pastry formulations. Generally, the amount of flour required in the formulation is more for croissants than doughnuts. Also, higher carbohydrate content (based on the proximate 

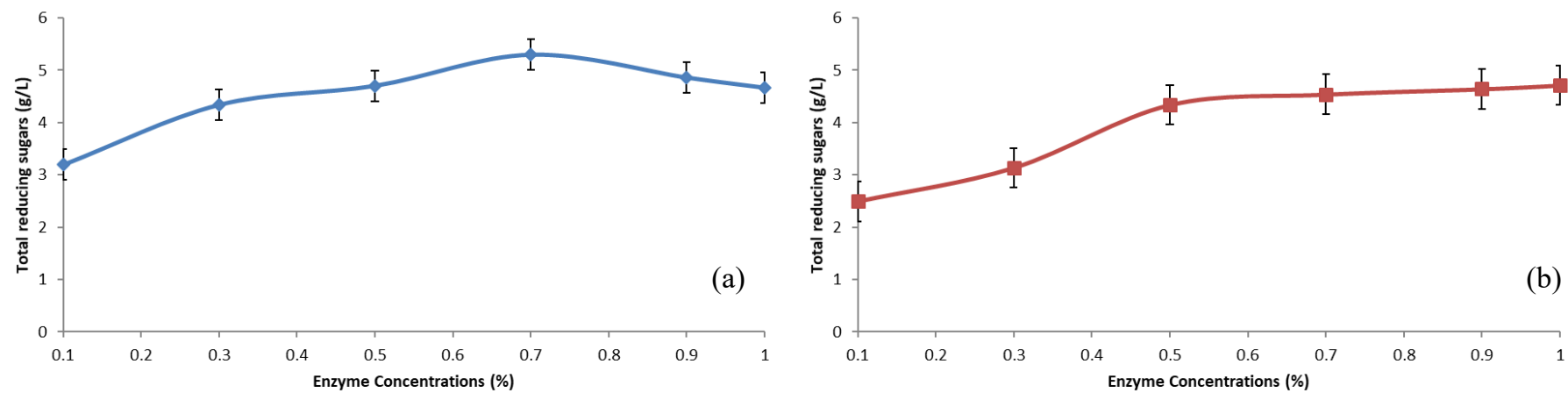

Figure 1. Total reducing sugar from the enzymatic hydrolysis of (a) leftover croissants ( $\downarrow)$ and (b) leftover doughnuts ( $\mathbf{\square})$ at different enzyme concentrations.

analysis) of leftover croissants $(50.07 \pm 2.49 \%)$ over doughnuts $(44.94 \pm 1.69 \%)$, had significantly contributed to a higher total reducing sugar produced through the enzymatic hydrolysis.

\section{Conclusion}

The croissants and doughnuts leftover $(0.05 \%, \mathrm{w} / \mathrm{v})$ have been hydrolyzed into total reducing sugar, $5.30 \pm 0.03 \mathrm{~g} / \mathrm{L}$ and $4.71 \pm 0.54 \mathrm{~g} / \mathrm{L}$ respectively. As being one of the most abundance wastes, pastry products have high potential as renewable resources. Using enzymatic hydrolysis process, it is proven that pastry leftover can be used as raw materials for recovering potential valueadded food ingredient (sugar) or as a raw material for further renewal process, such as in biofuel production.

\section{Acknowledgement}

This study was supported by Geran Putra IPS and the Fundamental Research Grant Scheme (FRGS) provided by the Ministry of Higher Education Malaysia.

\section{References}

AOAC. (2000). Official Methods of Analysis of AOAC International, $17^{\text {th }}$ ed. Maryland: AOAC International.

Adhikari, B.K., Barington, S. and Martinez, J. (2006). Predicted growth of world urban food waste and methane production. Waste Management and Research, 24(5), 421-433. https:// doi.org/10.1177/0734242X06067767

Chaplin, M. and Kennedy, J. (1986). Carbohydrate Analysis: A Practical Approach. Washington, DC: IRL Press.

Chen, M., Zhao, J. and Xia, L. (2008). Enzymatic hydrolysis of maize straw polysaccharides for the production of reducing sugars. Carbohydrate Polymers, 71(3), 411-415. https://doi.org/10.1016/ j.carbpol.2007.06.011

Demirci, A., Palabiyik, I., Gümüs, T. and özalp, S. (2017). Waste bread as a biomass source:
Optimization of enzymatic hydrolysis and relation between rheological behavior and glucose yield. Waste and Biomass Valorization, 8(3), 775-782. https://doi.org/10.1007/s12649-016-9601-6

Foist, L. (2018). Reducing vs. non-reducing sugars: definition and comparison. Retrieved from Study.com website: https://study.com/academy/ lesson/reducing-vs-non-reducing-sugars-definitioncomparison.html\#/partialRegFormModal

Holck, J., Hjerno, K. and Lorentzon, A. (2011). Tailored enzymatic production of oligosaccharides from sugar beet pectin and evidence of differential effects of a single DP chain length difference on human faecal microbiota composition after in vitro fermentation. Process Biochemistry, 46(5), 1039-1049. https:// doi.org/10.1016/j.procbio.2011.01.013

Hudečková, H., Šupinová, P. and Babák, L. (2017). Optimization of enzymatic hydrolysis of waste bread before fermentation. Acta Universitatis Agriculturae Et Silviculturae Mendelianae Brunensis, 65(1), 3540. https://doi.org/10.11118/actaun201765010035

Klinchongkon, K., Khuwijitjaru, P., Wiboonsirikul, J. and Adachi, S. (2017). Extraction of oligosaccharides from passion fruit peel by subcritical water treatment. Journal of Food Process Engineering, 40(1), 1-8. https://doi.org/10.1111/ jfpe.12269

Kunz, T., Lee, E., Schiwek, V., Seewald, T. and Methner, F.-J. (2011). Glucose- a reducing sugar? Reducing properties of sugars in beverages and food. Brewing Science, 64, 61-67.

Melikoglu, M. and Webb, C. (2013). Use of waste bread to produce fermentation products. In Kosseva, M. and Webb, C. Food industry waste: Assessment and recuperation of commodities, p. 63-76. Amsterdam: Academic Press. https://doi.org/10.1016/B978-0-12391921-2.00004-4

Menezes, C.R., Silva, I.S. and Pavarina, E.C. (2009). Production of xylooligosaccharides from enzymatic hydrolysis of xylan by the white-rot fungi Pleurotus. International Biodeterioration and Biodegradation, 
63(6), 637-678. https://doi.org/10.1016/

j.ibiod.2009.02.008

Ramirez-Coutino, L., Maria-Cervantes, M.C., Huerta, S., Revah, S. and Shirai, K. (2006). Enzymatic hydrolysis of chitin in the production of oligosaccharides using Lecanicillium fungicola chitinases. Process Biochemistry, 41(5), 1106-1110. https://doi.org/10.1016/j.procbio.2005.11.021

Sun, Y. and Cheng, J. (2002). Hydrolysis of lignocellulosic materials for ethanol production: a review. Bioresource Technology, 83(1), 1-11. https:// doi.org/10.1016/S0960-8524(01)00212-7 